\title{
Effect of $\beta$-Glucosidase Activity on the Vanillin Enzymatic Formation by Using Rumen Liquid for Cell Walls Degradation
}

\author{
Vita Paramita ${ }^{1} \&$ Mohamad Endy Yulianto ${ }^{1}$ \\ ${ }^{1}$ Department of Chemical Engineering, Diponegoro University, Semarang, Indonesia \\ Correspondence: Vita Paramita, Department of Chemical Engineering, Diponegoro University, Semarang, Jl. H. \\ Prof. Sudarto, SH, Tembalang 50275, Indonesia. Tel: 62-24-7079-9459. E-mail: vita.paramita@gmail.com
}

\author{
Received: September 27, 2012 Accepted: February23, 2013 Online Published: March 20, 2013 \\ doi:10.5539/jfr.v2n2p65 \\ URL: http://dx.doi.org/10.5539/jfr.v2n2p65
}

\begin{abstract}
This work proposed a study of direct enzymatic of vanillin formation by using rumen fluid which has enzymatic capability for tissue disruption of vanilla green pods to avoid the curing process. Application of enzymes during the formation of vanilla aromas and flavors and its extraction present nice opportunity to improve productivity, as the enzymatic reaction possibly substitute the microbial process in the traditional fermentation. Glucovanillin, the precursor of vanillin, contacted with the $\beta$-glucosidase in the green pods by destructing the cell wall. Liquid rument was providing enzyme for cell wall degradation. The contact of glucovanillin and $\beta$-glucosidase lead the hydrolysis of glucovanillin into vanillin. The amounts of glucovanillin and vanillin were examined by using HPLC analysis. The identification of vanillin was investigated by using liquid chromatography-mass spectrofotometry. Vanillin content of vanilla green pods was found higher in which by treating the vanilla green pods at $30^{\circ} \mathrm{C}$.
\end{abstract}

Keywords: glucovanillin, vanillin, $\beta$-glucosidase, vanilla pods, enzymatic extraction

\section{Introduction}

The tropical vanilla orchid is one of the most popular flavor sources in the food application. The smooth and gentle flavor of vanilla is a natural extracted oleoresin from the matured bean or pod of Vanilla planifolia Andrews. Walton, Mayer and Narbad (2003) claimed that natural vanillin from Vanilla green pods produced not more than $1 \%$ of vanillin production annually, with fluctuate value among $\$ 1200$ and $\$ 4000$ per kilo. The rest is possibly synthesised by bio or chemical processes (Labuda, Goers, \& Keon, 1992; Rao \& Ravishankar, 2000; Kumar, Sharma, \& Mishra, 2012) with very inexpensive cost, less than $\$ 15$ per kilo. Since natural vanillin provides its premium aroma which impossible to be reproduced by synthetic products and remains limited supply, they have important meaning in the flavor market (Lomascolo, Stentelaire, Asther, \& Lesage-Meessen, 1999; Muheim \& Lerch, 1999; Sinha,U. K. Sharma, \& N. Sharma, 2008). Moreover, the expensive price of the natural vanillin extracted due to its complex treatment both on the harvesting and vanillin formation process.

The main component of vanilla flavor, vanillin (4-hydroxy-3-methoxybenzaldehyde), in the vanilla pods exists in its conjugate form of $\beta$-D-glucoside without release the specific aroma of vanilla (Walton et al., 2003). Odoux, Escoute, Verdeil and Brillouet (2003a) includes the aroma precursors of vanilla, in which mainly obtained by vanillin $\beta$-D-glucoside (or glucovanillin), and minor glycosides of $\mathrm{p}$-hydroxybenzaldehyde, $\mathrm{p}$-hydroxybenzoic acid, vanillic acid (Leong, Archavlis, \& Derbesy, 1989) and p-hydroxybenzylalcohol (Kanisawa, 1993). Vanillin formation in the green pods performs as not as simple process than it can be imagined. The generation and release of aromatic compounds of vanilla flavour are the result of aroma precursor's hydrolysis by $\beta$-D-glucosidase activity during curing process (Odoux, 2000; General, Mamatha, Divya, \& Appaiah, 2009). Curing process is required for vanillin formation inteded for contacting the aroma precursor and the $\beta$-D-glucosidase which probably located not in the same tissue (Odoux et al., 2003a). Then, by destructing the plant cell wall, glucovanillin can be hydrolyzed into vanillin during the early stage of curing process, with no longer increasing of vanillin content during the drying or final stage of conventional curing process (Odoux, Chauwin, \& Brillouet, 2003b; Perera \& Owen, 2010).

Modifying the traditional curing process by using exogenous enzymes seems to be interesting to improve the vanillin formation from $2 \%$ on a dry weight basis by conventional curing process to more than double, as it might substitute the microbial process during conventional tissue fermentation (Brunerie, 1998; Perera \& Owen, 
2010; Labuda \& Norwood, 2010). Ruiz-Terán, Perez-Amador, \& López-Munguia (2001) and Waliszewski, Ovando and Pardio (2007) studied the conversion of glucovanillin into vanillin by treating the beans using exogenous enzymes in pure form to destruct the cell wall. They also mentioned that enzymatic pretreatment enriches and can as much as double vanillin content in the extract.Recently, Naidu et al. (2012) studied the application of tea leaf enzyme extract (TLEE) in the vanilla aroma's production from its fresh green pods. This study was done to overcome the expensive process of natural vanilla flavor formation in industrial scale by using pure form of enzymes.

This work proposed a study of a direct enzymatic of vanillin formation by using rumen fluid which has enzymatic capability for tissue disruption of vanilla green pods to avoid the curing process. The purpose of this study was to evaluate the effect of hydration time of vanilla beans in water and enzymatic conditions ( $\mathrm{pH}$ and temperature). There are several factors resulted in the activation enzyme during hydrolysis.

\section{Method}

\subsection{Materials}

Fresh green vanilla pods were collected from the region of Salatiga, Indonesia, before the curing process is begun. Pods were kept at $4{ }^{\circ} \mathrm{C}$ until the extraction process. Rumen fluid, which containing selulase, hemiselulase and pectinase, were obtained from the region of Semarang, Indonesia. Water, acetic acid, ethanol, and methanol of HPLC grade were obtained from Merck (Darmstadt, Germany).

\subsection{Enzymatic Extraction}

Fifty grams of cut green vanilla pods in pieces of $\sim 0.5 \mathrm{~cm}$ were placed in jacketed beakers. One hundred fifty millilitres of distilled water were added and the extraction was performed. The rumen fluid was added, with the temperature hold at 30 and $40^{\circ} \mathrm{C}$ for $6,12,18,24,30$ and $36 \mathrm{~h}$. All of the reaction contents were kept in suspension by agitation using a magnetic stirrer. The amount of vanillin and glucovanillin were quantified by using HPLC. In addition, the amount of glucose were quantified by spectrofotometry analysis. The analyses were carried out again after the addition of ethanol to reach $47.5 \% \mathrm{v} / \mathrm{v}$ concentration in the enzyme reaction mixture, allowing $30 \mathrm{~min}$ to complete the extraction.

\subsection{HPLC Analysis}

Concentration of glucovanillin and vanillin were analyzed by using High Performance Liquid Chromatography Alliance 2695 with Photodiode Array Detector 2996 (Water Corporation, USA). One millilitre of samples were centrifuged for $10 \mathrm{~min}$ at $13,000 \mathrm{rpm}$ and separated the filtrat. Ten microlitres of sample was then injected into HPLC.The columns applied was Symmetry C18, $5 \mu \mathrm{m}, 250 \times 4.6 \mathrm{~mm}$ with $1 \mathrm{ml} / \mathrm{min}$ of flow rate. The mobile phase were $\mathrm{H}_{2} \mathrm{O}$ pH 4 (adjusted with acetic acid, A) and methanol (B) as follows: $90-10 \%$ of acidified water/methanol for $0,01 \mathrm{~min} ; 90-10 \%$ of acidified water/methanol for $3 \mathrm{~min} ; 50-50 \%$ of acidified water/methanol for $23 \mathrm{~min}$; $0-100 \%$ of acidified water/methanol for $25 \mathrm{~min}$; $0-100 \%$ of acidified water/methanol for $27 \mathrm{~min}$; 90-10\% of acidified water/methanol for $28 \mathrm{~min}$; $90-10 \%$ of acidified water/methanol for $35 \mathrm{~min}$. Standard curves were obtained using vanillin and ethylvanillin (Sigma-aldrich, USA).

\subsection{Spectrofotometer Analysis}

The reducing sugars release were determined by the 3,5-dinitrosalicylic acid method (Breuil \& Saddler, 1985) by using UV-Visible recording spectrophotometer (UV-160A, Shimadzu, Japan). Samples taken at 0, 6, 12, 24, 30 and 36 hours.

\subsection{Data Treatment}

The measurement of the amount of vanillin was done in once.

\section{Results}

\subsection{Detection of Glucovanillin and Vanillin by Using Liquid Chromatogram-Mass Spectrofotometry}

The detection of glucovanillin and vanillin was applied by using liquid chromatography-mass spectrofotometry. Figure 1 shows that glucovanillin can be detected on minutes to 12.46 and vanillin was detected on minutes to 19.3. The area of glucovanillin was found quite narrow. This result affected on the final result of glucovanillincontent, nearly $0 \mathrm{ppm}$. On minutes to 12.9 , a dominan peak appeared, which was it has possibility of threonic acid. Sinha et al. (2008) reviewed that vanillin content can be analyzed by using liquid chromatography-mass spectrofotometry and liquid chromatography-ultra violet. Moreover, liquid chromatography-mass spectrofotometry found to be more precise because it has higher level of specificity. 


\subsection{Effect of Temperature on the Vanillin Content}

Before treating the green vanilla pods, the initial vanillin content was analyzed. The initial vanillin content was found $10.0 \mathrm{ppm}$. Figure 2 shows the result of fermented vanillin content after cell wall hydrolysis by using liquid rumen. The liquid rument appliedsince it provides many kind of enzymes activity (Lee et al., 2002). Lee, Shin, Kim, Ha and Han (1999) represent that the rumen liquid obtained more attention due to their advanced polysaccharide-degrading enzymes, mainly, cellulase and xylanase wihich were produced by ruminal anaerobic fungi.

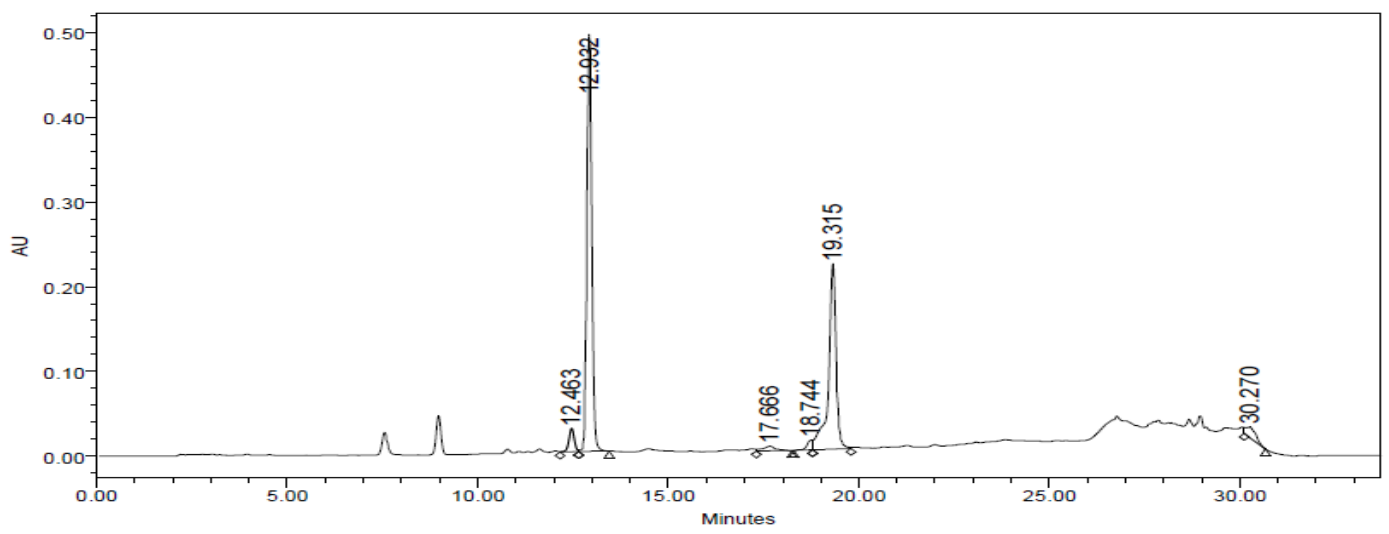

Figure 1. The LC-MS chromatogram ethanolic extract of pods of Vanilla planifolia

The vanillin content was found higher in the temperature of $30^{\circ} \mathrm{C}$ comparing to the vanilla green pods treated at $40^{\circ} \mathrm{C}$. Treating the vanilla green pods on the $30^{\circ} \mathrm{C}$ resulting the vanillin content of $376 \mathrm{ppm}$ after 12 hours. However, 12 hours of treating vanilla green pods on the $40^{\circ} \mathrm{C}$ resulting the vanillin content of $178 \mathrm{ppm}$. However, the longertreatment of the vanilla pods resulting lower content of vanillin. This results indicated that there is a possibility of formation others compounds besides vanillin and glucose.

Ruiz-Terán et al. (2001) analyzed the vanillin content extracted from vanilla pods, which were resulted 1.17 $\mathrm{g} / 100 \mathrm{~g}$ of dry pods and $2.66 \mathrm{~g} / 100 \mathrm{~g}$ of dry pods while extracted by using ethanol. This result shows that ethanol has significant effect on the vanillin extraction. Nevertheles, this work resulted the opposite from the previous work. Extracted vanillin content (302.3 ppm) found much more lower than vanillin content which were obtained during hydrolysis-fermentation process (184.6 ppm).

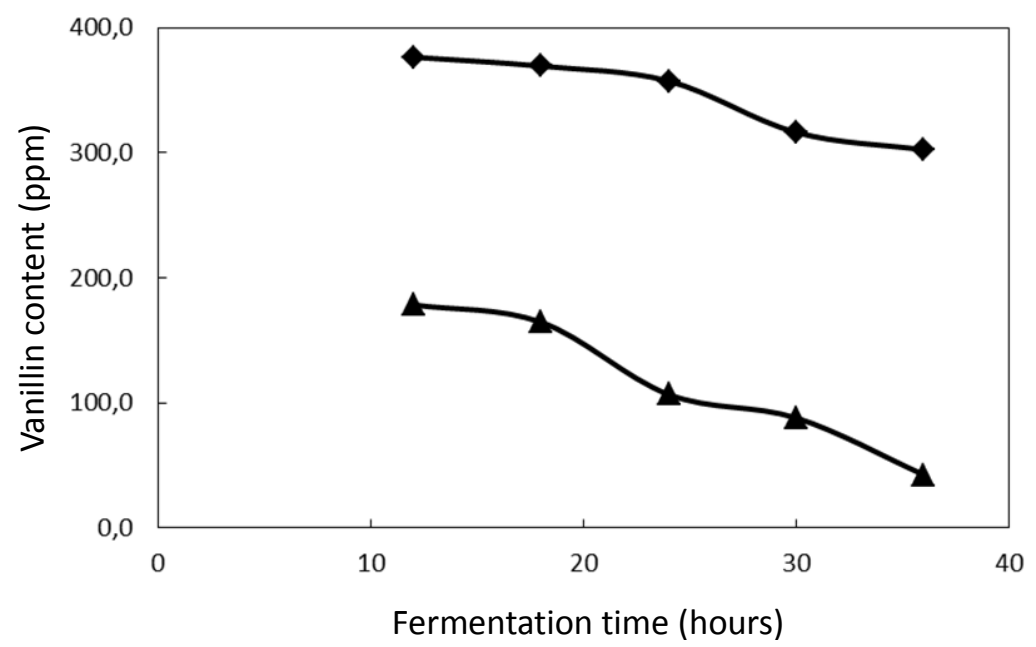

Figure 2. Vanillin content extracted from green vanilla pods and obtained during hydrolysis-fermentation process. Fermentation condition: $\mathrm{pH} 7$; temperature: $30^{\circ} \mathrm{C}(\bullet)$ and $40^{\circ} \mathrm{C}$ 


\section{Discussion}

Liquid rument was providing enzyme for cell wall degradation in order to support the hydrolysis process of glucovanillin. Vanillin content of vanilla green pods was found higher in which by treating the vanilla green pods at $30^{\circ} \mathrm{C}$. Nevertheless, the addition of ethanol, resulted lower vanillin content. These results need more research in order to understand the contact mechanism of glucovanillin and $\beta$-glucosidase. Moreover, economically analysis would be interesting area to understand the effective application of this method.

\section{Acknowledgements}

This work was supported by the Grant-in-Aid for Scientific Research (No. 261.13/UN7.5/PG.2012) form the Ministry of Education and Culture of Indonesia. Thank you for Dr. AnisMahsunah from Research Center of LIPI (Tangerang, Indonesia) for providing the analysis of this work.

\section{References}

Breuil, C., \& Saddler, J. N. (1985). Comparison of the 3,5-dinitrosalicylic acid and nelson-somogyi methods of assaying for reducing sugars and determining cellulase activity. Enzyme and Microbial Technology, 7(7), 327-332. http://www.sciencedirect.com/science/article/pii/0141022985901115

Brunerie, P. M. (1998). Process for the production of natural vanilla extract by enzymatic processing of green vanilla pods, and extract thereby obtained. US Patent. Retrieved from http://www.google.com/patents?id=MJcbAAAAEBAJ\&printsec=abstract\&zoom=4\#v=onepage\&q\&f=false

Chauve, M., Mathis, H., Huc, D., Casanave, D., Monot, F., \& Ferreira, N. L. (2010). Comparative kinetic analysis of two fungal $\beta$-glucosidases. Bioechnology for Biofuels, 3(3). Retrieved March 11, 2012, from http://www.biomedcentral.com/content/pdf/1754-6834-3-3.pdf

General, T., Mamatha, V., Divya, V., \& Appaiah, K. A. A. (2009). Diversity of yeast with $\beta$-glucosidase activity in vanilla (Vanilla planifolia) plan. Current Science, 96(11), 1501-1505.

Himmel, M. E., Adney, W. S., Fox, J. W., Mitchell, D. J., \& Baker, J. O. (1993). Isolation and characterization of two forms of beta-d-glucosidase from Aspergillusniger. Applied Biochemistry and Biotechnology, 39-40, 213-225. http://www.ncbi.nlm.nih.gov/pubmed/8323261.

Kanisawa, T. (1993). Flavor development in vanilla beans.Kouryou, 180, 113-123.

Labuda, I. M., Goers, S. K., \& Keon, K. A. (1992). Bioconversion process for the production of vanillin. Retrieved from http://www.google.com/patents?id=DuQiAAAAEBAJ\&printsec=abstract\&zoom=4\#v=onepage\&q\&f=false

Labuda, I., \& Norwood, N. J. (2010). Enzymatic treatment of spent vanilla beans. Retrieved from http://www.google.com/patents?id=zJvWAAAAEBAJ\&printsec=abstract\&zoom=4\#v=onepage\&q\&f=false

Lee, S. S., Shin, K. J., Kim, W. Y., Ha, J. K., \& Han, I. K. (1999). The rumen ecosystem: as a fountain source of nobel enzymes. Asian-Australasian Journal of Animal Sciences, 12(6), 988-1001. Retrieved fromhttp://readermeter.org/Shin.K_J/fe5bfa00-6d0c-11df-afb8-0026b95d30b2/details

Lee, S. S., Kim, C. H., Ha, J. K., Moon, Y. H., Choi, N. J., \& Cheng, K. J. (2002). Distribution and activities of hydrolytic enzymes in the rument compartments of hereford bulls fed alfalfa based diet. Asian-Australasian Journal of Animal Sciences, 15(12), 1725-1731. http://www.ajas.info/Editor/manuscript/upload/15_274.pdf

Leong, G., Archavlis, A., \& Derbesy, M. (1989). Research on the glucoside fraction of the vanilla bean.Journal of Essential Oil Research, $\quad 1(1), \quad 33-41$. http://www.tandfonline.com/doi/abs/10.1080/10412905.1989.9699442

Lomascolo, A., Stentelaire, C., Asther, M., \& Lesage-Meessen, L. (1999). Basidiomycetes as new biotechnological tools to generate natural aromatic flavours for the food industry.Trends in Biotechnology, 17(7), 282-289. http://www.cell.com/trends/biotechnology/abstract/S0167-7799(99)01313-X

Muheim, A., \& Lerch, K. (1999). Towards a high-yield conversion of ferulic acid to vanillin. Applied Microbiology and Biotechnology, 51(4), 456-461. http://www.springerlink.com/content/yhxpdrkgm618b2du/

Naidu, M. M., Kumar, P. V. S., Shyamala, B. N., Sulochanamma, G., Prakash, M., \& Thakur, M. S. (2012). Enzyme-assisted process for production of superior quality vanilla extracts from green vanilla pods using tea leaf enyzmes. Food and Bioprocess Technology, 5, 527-532. http://www.springerlink.com/content/3171j300t2340348/

Odoux, E. (2000). Changes in vanillin and glucovanillin concentrations during the various stages of the process 
traditionally used for curing vanilla fragrans beans in Réunion. Fruits, 55, 119-125.

Odoux, E., Escoute, J., Verdeil, J. -L., \& Brillouet, J. -M. (2003a). Localization of $\beta$-D-glucosidase activity and glucovanillin in vanilla bean (vanilla planifoliaandrews). Annals of Botany, 92(3), 437-444. Retrieved from http://aob.oxfordjournals.org/content/92/3/437.full.pdf

Odoux, E., Chauwin, A., \& Brillouet, J. -M. (2003b). Purification and characterization of vanilla bean (vanilla planifoliaandrews) $\beta$-D-glucosidase. Journal of Agricultural and Food Chemistry, 51(10), 3168-3173. http://pubs.acs.org/doi/abs/10.1021/jf0260388

Perera, C. O., \& Owen, E. (2010). Effect of tissue disruption by different methods followed by incubation with hydrolyzing enzymes on the production of vanillin from tongan vanilla beans. Food and Bioprocess Technology, 3(1), 49-54. http://rd.springer.com/article/10.1007/s11947-007-0048-4

Rao, S. R., \& Ravishankar, G. A. (2000). Vanilla flavour: production by conventional and biotechnological routes. Journal of the Science of Food and Agriculture, 80, 289-304. Retrieved from http://onlinelibrary.wiley.com/doi/10.1002/1097-0010(200002)80:3\%3C289::AID-JSFA543\%3E3.0.CO;2-2 /abstract

Ruiz-Terán, F., Perez-Amador, I., \& López-Munguia, A. (2001). Enzymatic extraction and transformation of glucovanillin to vanillin from vanilla green pods.Journal of Agricultural and Food Chemistry, 49(11), 5207-5209. Retrieved from http://pubs.acs.org/doi/abs/10.1021/jf010723h

Sinha, A. K., Sharma, U. K., \& Sharma, N. (2008). A comprehensive review on vanilla flavor: extraction, isolation and quantification of vanillin and others constituents. International Journal of Food Sciences and $\begin{array}{llll}\text { Nutrition, } & 59(4), & 299-326 . & \text { Retrieved }\end{array}$ http://informahealthcare.com/doi/abs/10.1080/09687630701539350

Waliszewski, K., Ovando, S., \& Pardio, V. (2007). Effect of hydration and enzymatic pretreatment of vanilla beans on the kinetics of vanillin extraction. Journal of Food Engineering, 78(4), 1267-1273. http://dx.doi.org/10.1016/j.jfoodeng.2006.01.029

Walton, N. J., Mayer, M. J., \& Narbad, A. (2003). Vanillin.Phytochemistry, 63(5), 505-515. Retrieved from http://www.ncbi.nlm.nih.gov/pubmed/12809710 